\title{
Analisis Pengaruh Struktur Modal, Ukuran Perusahaan, dan Agency Cost Terhadap Kinerja Perusahaan
}

\author{
Khaira Amalia Fachrudin \\ Fakultas Ekonomi Universitas Sumatera Utara \\ Email:khairaamalia@yahoo.co.id
}

\begin{abstract}
ABSTRAK
Penelitian ini bertujuan untuk menguji pengaruh struktur modal dan ukuran perusahaan terhadap agency cost; pengaruh struktur modal, ukuran perusahaan, dan agency cost terhadap kinerja perusahaan; serta pengaruh tidak langsung struktur modal dan ukuran perusahaan terhadap kinerja perusahaan melalui agency cost sebagai intervening variable. Populasi adalah perusahaan-perusahaan dalam industri dasar dan kimia yang terdaftar di Bursa Efek Indonesia tahun 2009. Dari populasi ini dipilih populasi sasaran yang semuanya menjadi sampel penelitian. Metode statistika yang digunakan adalah analisis jalur. Hasil pengujian menunjukkan bahwa terdapat pengaruh signifikan positif struktur modal terhadap agency cost dan pengaruh signifikan negatif ukuran perusahaan terhadap agency cost; tidak terdapat pengaruh signifikan struktur modal, ukuran perusahaan, dan agency cost terhadap kinerja perusahaan; serta tidak terdapat pengaruh tidak langsung struktur modal dan ukuran perusahaan terhadap kinerja perusahaan melalui agency cost sebagai intervening variable.
\end{abstract}

Kata kunci: Struktur modal, ukuran perusahaan, agency cost, kinerja perusahaan, analisis jalur

\begin{abstract}
The purpose of this research is to examine the effect of capital structure and firm size on agency cost; the effect of capital structure, firm size, and agency cost on firm performance; and the indirect effect of capital structure and firm size on firm performance by agency cost as intervening variable. The population is basic and chemical industry companies registered at the Indonesian Stock Exchage in 2009. The population was selected to get target population which become the sample of this study. The statistics method which used to test hypotheses is path analysis. The results show that: positive significant effect of capital structure and negative significant effect of firm zize on agency cost; insignificant effect of capital structure, firm size, and agency cost on firm performance; insignificant indirect effect of capital structure and firm size on firm performance by agency cost as intervening variables.
\end{abstract}

Keywords: Capital structure, firm size, agency cost, firm performance, path analysis.

\section{PENDAHULUAN}

Tujuan utama didirikannya perusahaan adalah untuk meningkatkan kesejahteraan pemegang saham. Kesejehteraan dapat ditingkatkan melalui kinerja perusahaan (firm performance) yang baik. Kinerja perusahaan yang baik juga bermakna bagi konsumen, komunitas, karyawan, dan pemasok - termasuk dalam pemasok adalah kreditur, yaitu pemasok dana. Tujuan sekunder didirikannya perusahaan adalah untuk kesejah- teraan pihak-pihak yang disebutkan terakhir. Tujuan sekunder adalah penggerak bagi tercapainya tujuan primer (Atkinson, Banker, Kaplan, and Young 1997).

Kinerja perusahaan memperlihatkan kemampuan perusahaan untuk memberikan keuntungan dari aset, ekuitas, maupun hutang. Kinerja perusahaan merupakan prestasi kerja perusahaan. Salah satu ukuran kinerja perusahaan adalah Return on Equity (ROE). ROE adalah ukuran profitabilitas perusahaan penting 
yang mengukur pengembalian untuk pemegang saham (Jones et al. 2009).

Di dalam perusahaan terdapat beberapa fungsi, antara lain fungsi pengelolaan dan fungsi kepemilikan. Jensen dan Meckling (1976) mengatakan bahwa pemisahan fungsi pengelolaan dan fungsi kepemilikan sangat rentan dengan agency conflict (konflik kepentingan). Agency conflict terjadi manakala manajer cenderung membuat keputusan yang menguntungkan dirinya daripada kepentingan pemegang saham (Meckling 1976, Myers 1977). Agency conflict dapat menimbulkan agency cost (biaya agensi), yaitu berupa pemberian insentif yang layak kepada manajer serta biaya pengawasan untuk mencegah hazard. Agency cost juga berarti penggunaan aliran kas untuk bonus atau pengeluaranpengeluaran yang tidak perlu yang dilakukan manajer atas free cash flow (aliran kas bebas).

Agency conflict dapat terjadi antara pemegang saham pengendali dan pemegang saham minoritas, antara pemegang saham dengan kreditur, antara pemegang saham pengendali dan stakeholder lainnya, termasuk pemasok dan karyawan (Asian Development Bank dalam Husnan, 2001). Tetapi penelitian ini hanya terbatas pada agency conflict antara manajer dan pemegang saham.

Perusahaan dapat didanai dengan hutang dan ekuitas. Komposisi penggunaan hutang dan ekuitas ini tergambar dalam struktur modal. Penggunaan hutang diistilahkan dengan financial leverage (pengungkit keuangan). Hutang (debt) yang dimaksud adalah hutang untuk pendanaan perusahaan yang tidak selalu sama dengan kewajiban (liabilities) dan tidak sama dengan tagihan (payable). Hutang menimbulkan beban bunga yang dapat menghemat pajak. Artinya beban bunga dapat dikurangkan dari pendapatan sehingga laba sebelum pajak menjadi lebih kecil dan akibatnya pajak semakin kecil. Sedangkan jika pendanaan menggunakan ekuitas, maka tidak terdapat beban yang dapat mengurangi pajak perusahaan.

Dalam literatur finance, Jensen dan Meckling (1976) adalah yang pertama menghubungkan agency cost dengan hutang dalam struktur modal. Penggunaan hutang dalam struktur modal dapat mencegah pengeluaran perusahaan yang tidak penting dan memberi dorongan pada manajer untuk mengoperasikan perusahaan dengan lebih efisien. Hal tersebut menyebabkan agency cost berkurang dan selanjutnya kinerja perusahaan diharapkan akan meningkat Cao (2006).

Penggunaan hutang yang tinggi dalam struktur modal mungkin mempengaruhi perilaku manajer. Jika keadaan baik, manajer akan menggunakan aliran kas untuk bonus atau pengeluaran-pengeluaran tidak perlu yang disebut agency cost. Tetapi ancaman kebangkrutan karena hutang yang tinggi dapat mengurangi pengeluaran yang tidak penting sehingga akan meningkatkan free cash flow (aliran kas bebas). Dengan demikian diharapkan hutang tersebut dapat mengurangi agency cost. Agency cost dapat pula terjadi jika manajer tidak menangkap peluang investasi pada proyek baru karena khawatir akan resiko yang akan ditanggungnya (Brigham dan Daves 2004). Lin (2006) menemukan bahwa struktur modal berpengaruh positif terhadap agency cost, artinya kebijakan hutang meningkatkan agency cost.

Selain pengaruh struktur modal terhadap agency cost, Lin (2006) juga menemukan bahwa ukuran perusahaan berpengaruh negatif terhadap agency cost, mengindikasikan bahwa perusahaan besar memerlukan lebih sedikit beban-beban discretionary.

Berdasarkan hal tersebut di atas maka diajukan hipotesis pertama sebagai berikut:

$\mathrm{H}_{1}$ : Terdapat pengaruh struktur modal dan ukuran perusahaan terhadap agency cost.

ROE dapat menjadi ukuran efisiensi penggunaan modal sendiri yang dioperasionalkan dalam perusahaan. Semakin besar ROE, semakin besar pula kemampuan perusahaan menghasilkan laba bagi pemegang saham. Moeljadi (2006) mengatakan bahwa leverage merupakan variabel penjelas bagi rentabilitas modal sendiri. Maksudnya struktur modal merupakan variabel penjelas bagi ROE.

Brigham dan Houston (2001) menyatakan bahwa leverage keuangan merupakan alternatif yang dapat digunakan untuk meningkatkan laba. Penggunaan hutang dalam investasi sebagai tambahan untuk mendanai aktiva perusahaan diharapkan dapat meningkatkan keuntungan yang akan diperoleh perusahaan, karena aktiva perusahaan digunakan untuk menghasilkan laba. Dengan demikian laba yang tersedia untuk pemegang ekuitas menjadi lebih besar (Brigham dan Houston 2001). Tetapi, penggunaan leverage yang semakin besar menyebabkan beban bunga semakin besar (Brigham dan Gapenski 1997). Jika beban bunga sangat besar sedangkan laba operasi tidak cukup besar maka akan timbul masalah kesulitan keuangan yang menyebabkan kinerja menurun. Namun demikian beban bunga hutang juga merupakan pengurang pajak yang dapat meningkatkan nilai perusahaan (Brigham dan Gapenski 1997). Dalam hal ini dapat dikatakan bahwa hutang dapat meningkatkan kinerja. Sedangkan bila perusahaan mengguna- 
kan ekuitas maka tidak terdapat penghematan pajak karena beban ekuitas tidak mengurangi pajak. Bouresli (2001) dan Lin (2010) menemukan bahwa rasio hutang terhadap jumlah aset berpengaruh negatif terhadap kinerja perusahaan, tetapi Calisir et al. (2010) menemukan pengaruh yang positif.

Lin (2006) serta Wright et al. (2009) menemukan bahwa ukuran perusahaan berpengaruh positif terhadap kinerja. Hal ini menunjukkan bahwa perusahaan besar lebih menjanjikan kinerja yang baik (Lin, 2006). Calisir et al. (2010) juga menemukan pengaruh positif ukuran perusahaan terhadap kinerja perusahaan sektor teknologi informasi dan komunikasi di Turki. Tetapi Huang (2002) menemukan bahwa tidak terdapat pengaruh ukuran perusahaan terhadap kinerja perusahaan Taiwan yang berada di China. Demikian juga Talebria et al. (2010), tidak menemukan pengaruh ukuran perusahaan terhadap kinerja perusahaan yang terdaftar di Tehran Stock Exchange.

Lin (2006) juga meneliti pengaruh agency cost terhadap ROE. Ditemukan bahwa agency cost berpengaruh negatif dan signifikan terhadap ROE. Demikian juga Wright et al. (2009), menemukan bahwa agency cost berhubungan negatif dengan kinerja perusahaan. Sikap tidak peduli terhadap agency cost dapat mengurangi pencapaian keuntungan kompetitif yang berdampak negatif terhadap kinerja.

Dalam hipotesis pertama di atas telah diduga bahwa struktur modal dan ukuran perusahaan berpengaruh terhadap agency cost. Namun dari uraian Brigham dan Houston (2001) di atas terlihat bahwa struktur modal dapat juga berpengaruh langsung terhadap kinerja perusahaan. Demikian juga ukuran perusahaan dapat berpengaruh positif (Lin 2006, Wright et al. 2009, Calisir et al. 2010) terhadap kinerja perusahaan, walaupun dapat juga tidak berpengaruh (Huang 2002, Talebria et al. 2010). Lin (2006) dan Wright et al. (2009) menemukan bahwa agency cost berpengaruh terhadap kinerja perusahaan. Berdasarkan temuan-temuan tersebut maka dirumuskan hipotesis kedua, yaitu :

$\mathrm{H}_{2}$ : Terdapat pengaruh struktur modal, ukuran perusahaan, dan agency cost terhadap kinerja perusahaan.

Di atas telah disebutkan bahwa struktur modal dan ukuran perusahaan dapat berpengaruh terhadap agency cost. Agency cost yang diproksikan dengan rasio discretionary expense terhadap penjualan bersih pun dapat berpengaruh terhadap kinerja perusahaan (Lin 2006). Struktur modal dan ukuran perusahaan mungkin akan ber- pengaruh juga terhadap kinerja perusahaan melalui agency cost sebagai intervening variable. Artinya semakin tinggi tingkat hutang dan ukuran perusahaan dapat berpengaruh terhadap kinerja perusahaan jika dikaitkan dengan agency cost yang diproksikan dengan rasio discretionary expense terhadap penjualan bersih. Maksudnya jika hutang meningkatkan beban bunga maka discretionary expense dapat meningkat dan akibatnya menurunkan kinerja. Tetapi jika beban bunga tersebut menghemat pajak maka kinerja dapat meningkat. Hutang juga mungkin meningkatkan produktifitas sehingga penjualan meningkat. Dengan demikian rasio discretionary expense terhadap penjualan bersih yang merupakan proksi dari agency cost berkurang. Berkurangnya rasio tersebut menyebabkan laba meningkat, dan akibatnya kinerja meningkat. Demikian juga jika ukuran perusahaan meningkatkan skala ekonomis maka kemungkinan kinerja akan meningkat melalui pengurangan discretionary expense. Sebaliknya, jika ukuran yang besar menyebabkan peningkatan beban, maka kinerja akan menurun. Berdasarkan hal tersebut maka diajukan hipotesis ketiga sebagai berikut:

$\mathrm{H}_{3}$ : Terdapat pengaruh tidak langsung struktur modal dan ukuran perusahaan terhadap kinerja perusahaan melalui agency cost sebagai intervening variable.

Keterkaitan struktur modal, ukuran perusahaan, agency cost, dan kinerja perusahaan dapat dilihat dalam model penelitian seperti pada Gambar 1.

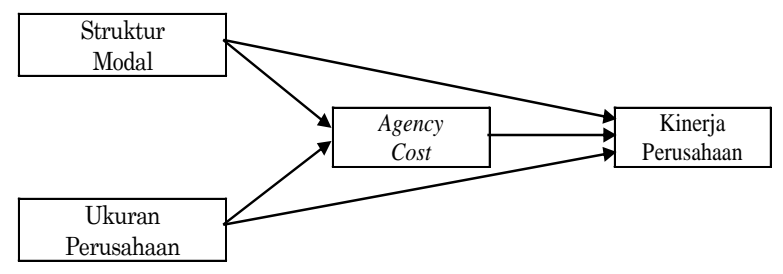

Sumber: Jensen dan Meckling (1976), (Brigham dan Gapenski 1997), Brigham dan Houston (2001), Brigham dan Daves (2004), Lin (2006), Wright, et al. (2009), Calisir et al. (2010), dimodifikasi

\section{Gambar 1. Model Penelitian}

Perumusan masalah adalah: 1) apakah terdapat pengaruh struktur modal dan ukuran perusahaan terhadap agency cost, 2) apakah terdapat pengaruh struktur modal, ukuran perusahaan, dan agency cost terhadap kinerja perusahaan, dan 3) apakah terdapat pengaruh tidak langsung struktur modal dan ukuran perusahaan terhadap kinerja perusahaan melalui 
agency cost sebagai intervening variable. Tujuan penelitian ini adalah untuk menguji secara empiris tentang 1) pengaruh struktur modal dan ukuran perusahaan terhadap agency cost, 2) pengaruh struktur modal, ukuran perusahaan, dan agency cost terhadap kinerja perusahaan, dan 3) pengaruh tidak langsung struktur modal dan ukuran perusahaan terhadap kinerja perusahaan melalui agency cost sebagai intervening variable. Secara teoritis, manfaat penelitian ini adalah memberi kontribusi bagi ilmu manajemen keuangan mengenai 1) pengaruh struktur modal dan ukuran perusahaan terhadap agency cost, 2) pengaruh struktur modal, ukuran perusahaan, dan agency cost terhadap kinerja perusahaan, dan 3) pengaruh tidak langsung struktur modal dan ukuran perusahaan terhadap kinerja perusahaan melalui agency cost sebagai intervening variable.. Selain itu diharapkan juga bahwa penelitian ini memberikan kontribusi bagi penelitian yang akan datang melalui model teoritikal yang diajukan.

Secara praktis, penelitian penting agar investor maupun calon investor dapat mengetahui faktor apa yang dapat meningkatkan kinerja perusahaan dan apakah memang terdapat indikasi masalah agency di dalam perusahaan. Bagi manajer hasil penelitian ini akan bermanfaat, yaitu apakah pendanaan dengan hutang yang meningkatkan beban perusahaan akan dapat tertandingi dengan beban pajak sehingga kinerja meningkat atau tidak.

\section{METODE PENELITIAN}

Populasi penelitian ini adalah perusahaan dalam industri dasar dan kimia yang terdaftar di Bursa Efek Indonesia tahun 2009. Jumlah populasi adalah 58 perusahaan. Populasi sasaran adalah perusahaan yang tidak mempunyai laba bersih negatif serta tidak mempunyai ekuitas negatif, yaitu 42 perusahaan. Semua perusahaan dalam populasi sasaran diobservasi (sampel jenuh). Data bersumber dari laporan keuangan perusahaan yang telah diaudit yang diunduh dari website Bursa Efek Indonesia, yaitu www.jsx.go.id. Fokus penelitian adalah perusahaan dalam industri dasar dan kimia.

Data yang digunakan adalah data sekunder historis yang bersifat cross section. Penelitian berupa penelitian ex post facto, karena data bersumber dari laporan keuangan emiten yang telah dipublikasikan dan digunakan tanpa merubahnya. Penelitian bersifat kausalitas, yaitu penelitian yang ingin mencari penjelasan dalam bentuk hubungan sebab akibat (cause-effect) antar beberapa variabel yang dikembangkan dalam manajemen (Ferdinand, 2006). Hipotesis yang disajikan adalah hipotesis kausalitas. Analisis data akan menghasilkan kesimpulan umum.

Analisis data dilakukan dengan analisis jalur. Analisis ini digunakan karena terdapat kemungkinan hubungan antarvariabel dalam model yang bersifat linier. Agency cost digunakan sebagai intervening variable karena pengaruh struktur modal dan ukuran perusahaan terhadap kinerja perusahaan dapat berhubungan secara konseptual dengan rasio discreationary expense terhadap penjualan sebagai proksi agency cost. Secara teori pengaruh struktur modal dan ukuran perusahaan terhadap kinerja perusahaan dapat terlihat secara langsung. Namun dapat pula dilihat melalui agency cost.

Tingkat kepercayaan yang digunakan adalah $95 \%$, yang berarti bahwa alpha adalah $5 \%$. Pengolahan data dilakukan dengan bantuan program aplikasi SPSS versi 17 .

Persamaan struktural untuk pengujian hipotesis pertama:

$\mathrm{Y}_{1}=\rho \mathrm{Y}_{1} \mathrm{X}_{1} \mathrm{X}_{1}+\rho_{1} \mathrm{X}_{2} \mathrm{X}_{2}+\mathrm{C}_{1}$

$\mathrm{Y}_{1}=$ variabel endogen agency cost

$\mathrm{X}_{1}=$ variabel eksogen struktur modal

$\mathrm{X}_{2}=$ variabel eksogen ukuran perusahaan

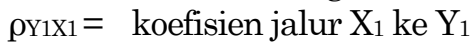

$\rho_{11 X 2}=$ koefisien jalur $\mathrm{X}_{2} \mathrm{ke}_{1}$

$\epsilon_{1}=$ koefisien jalur variabel error 1

Persamaan struktural untuk pengujian hipotesis kedua:

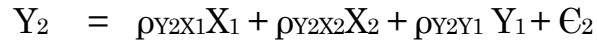

$\mathrm{Y}_{2}=$ variabel endogen kinerja perusahaan

$\mathrm{Y}_{1}=$ variabel endogen agency cost

$\mathrm{X}_{1}=$ variabel eksogen struktur modal

$\mathrm{X}_{2}=$ variabel eksogen ukuran perusahaan

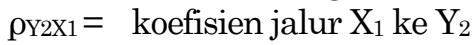

$\rho_{\mathrm{Y} 2 \mathrm{X} 2}=$ koefisien jalur $\mathrm{X}_{2}$ ke $\mathrm{Y}_{2}$

$\rho_{\mathrm{Y} 2 \mathrm{Y} 1}=$ koefisien jalur $\mathrm{Y}_{1}$ ke $\mathrm{Y}_{2}$

$\mathrm{C}_{2}=$ koefisien jalur variabel error 2

Perhitungan Pengaruh tidak langsung untuk pengujian hipotesis ketiga:

- Pengaruh tidak langsung (indirect effect) $\mathrm{X}_{1}$ $\mathrm{ke}_{2}$ melalui $\mathrm{Y}_{1}=\rho \mathrm{Y} 1 \mathrm{X} 1 \quad \mathrm{x}$ $\rho \mathrm{Y} 2 \mathrm{Y} 1$

- Pengaruh tidak langsung (indirect effect) $\mathrm{X}_{2}$ ke $\mathrm{Y}_{2}$ melalui $\mathrm{Y}_{1}=\rho \mathrm{Y} 1 \mathrm{X} 2 \quad \mathrm{x}$ คY2Y1

Variabel penelitian dan definisi operasional:

- $Y_{1}$ adalah rasio discretionary expense terhadap penjualan bersih, yang merupakan proksi agency cost (Lin, 2006). Discretionary expense adalah beban yang dikeluarkan berdasarkan kebijaksanaan seorang manajer. Beban ini meliputi beban operasi, beban non operasi, beban bunga, serta gaji dan upah (Lin 2006). Formula:

$$
\frac{\text { Discretoin ary expense }}{\text { Penjualan bersih }}
$$


- $\mathrm{Y}_{2}$ adalah kinerja perusahaan yang dalam hal ini diukur dengan ROE. Formula (Jones et al. 2009):

Laba bersih

Ekuitas pemegang saham

- $\mathrm{X}_{1}$ merupakan struktur modal atau rasio leverage, yaitu jumlah hutang terhadap jumlah ekuitas (Lin 2006). Rasio ini juga menunjukkan struktur modal perusahaan. Formula:

$$
\frac{\text { Jumlah hutang }}{\text { Jjmlah ekuitas }}
$$

- $\mathrm{X}_{2}$ merupakan ukuran perusahaan. Ukuran perusahaan dapat diukur dengan logaritma natural (natural log) dari jumlah aset (Naiker et al. 2008).

\section{HASIL PENELITIAN DAN PEMBAHASAN}

Berikut ini disajikan hasil uji statistik. Adapun data dan hasil pengolahannya secara lengkap ada pada penulis.

\section{Data Screening dan Transformasi Data}

Data awal yang dimasukkan berupa variabel struktur modal, ukuran perusahaan, dan agency cost tidak menunjukkan bahwa residual data tidak memenuhi asumsi normalitas. Untuk itu data ditransformasi dalam bentuk logaritma natural. Karena data sesuai populasi sasaran adalah data yang tidak memiliki laba bersih negatif dan tidak memiliki ekuitas negatif, maka seluruh data yang ditransformasi dapat terbaca oleh alat analisis. Pengujian Asumís Klasik yang dilakukan adalah:

\section{Pengujian Asumsi Klasik}

1. Uji Normalitas Residual

Statistik uji Kolmogorov-Smirnov menunjukkan p-value 0.180 (>0.05), yang menunjukkan bahwa asumsi normalitas residual telah terpenuhi

2. Uji Multikolinieritas

Nilai Tolerance masing-masing variabel adalah 0.961, yang lebih besar dari 0.1. Nilai VIF 1.040, yang lebih kecil dari 10. Hal ini menunjukkan bahwa tidak terjadi multikolonieritas.

3. Uji Heteroskedastisitas

Dengan uji Glejser ditemukan bahwa nilai signifikansi uji t adalah lebih besar dari alpha $5 \%$ yang menunjukkan bahwa data terbebas dari masalah heteroskedastisitas.

4. Uji Autokorelasi

Nilai Durbin-Watson adalah 2.219. Tabel Durbin-Watson untuk $\mathrm{k}=2$ dan $\mathrm{n}=42$ ditemukan $\mathrm{d}_{\mathrm{u}}=1.338$. Karena $1.338<2.219<$ 4- 1.338 atau $1.338<2.219<2.662$ maka hipotesis null yang menyatakan bahwa tidak terdapat autokorelasi positif maupun negatif tidak dapat ditolak.

\section{Penilaian Goodness of Fit Model}

1. Koefisien determinasi bernilai 0.303 yang berarti bahwa kemampuan model dalam menerangkan variasi variabel agency cost adalah sebesar $30.3 \%$, sedangkan sisanya sebesar $69.7 \%$ diterangkan oleh variabel lain yang tidak dimasukkan ke dalam model.

2. $\mathrm{Uji} F$

Signifikansi uji F bernilai 0.001. Nilai yang lebih besar daripada 5\% menunjukkan bahwa model yang digunakan adalah layak dan dapat digunakan untuk analisis selanjutnya.

3. Uji t

Struktur modal berpengaruh positif dan signifikan (p-value bernilai 0.010) terhadap agency cost. Sedangkan ukuran perusahaan berpengaruh negatif dan signifikan ( $p$-value bernilai 0.001) terhadap agency cost.

Tabel 1. Hasil Analisis Regresi Pengaruh $\mathrm{X}_{1} \operatorname{dan} \mathrm{X}_{2}$ terhadap $\mathrm{Y}_{1}$

\begin{tabular}{|c|c|c|c|c|c|c|c|c|}
\hline \multicolumn{9}{|c|}{ Coefficients $^{\mathrm{a}}$} \\
\hline \multirow[b]{2}{*}{ Model } & & \multicolumn{2}{|c|}{ Unstandardized Coefficients } & \multirow{2}{*}{$\begin{array}{c}\begin{array}{c}\text { Standardized } \\
\text { Coefficients }\end{array} \\
\text { Beta }\end{array}$} & \multirow[b]{2}{*}{$t$} & \multirow[b]{2}{*}{ Sig. } & \multicolumn{2}{|c|}{ Collinearity Statistics } \\
\hline & & B & Std. Error & & & & Tolerance & $\mathrm{MF}$ \\
\hline \multirow[t]{3}{*}{1} & (Constant) & 7.575 & 2.735 & & 2.770 & .009 & & \\
\hline & In debt to equity & .333 & 123 & .370 & 2.716 & .010 & .961 & 1.040 \\
\hline & Inta & .463 & .130 & .487 & -3.570 & .001 & .961 & 1.040 \\
\hline
\end{tabular}

a. Dependent Variable: Inagencycostinteres

Persamaan matematika model jalur 1:

$$
\mathrm{Y}_{1}=0,370 \mathrm{X}_{1}-0.487 \mathrm{X}_{2}+0.835 \mathrm{C}_{1}
$$

\section{Pengujian Hipotesis Kedua}

\section{$\underline{\text { Data Screening dan Transformasi Data }}$}

Sama seperti pengujian hipotesis pertama, residual data awal tidak berdistribusi normal sehingga data ditransformasi dalam bentuk logaritma natural.

\section{$\underline{\text { Pengujian Asumsi Klasik }}$}

1. Uji Normalitas Residual

Statistik uji Kolmogorov-Smirnov menunjukkan p-value 0.638 (>0.05), yang menunjukkan bahwa asumsi normalitas residual telah terpenuhi

2. Uji Multikolinieritas

Nilai Tolerance variabel struktur modal, ukuran perusahaan, dan agency cost masingmasing adalah 0.808, 0.724, dan 0.697 (lebih besar dari 0.1). Nilai VIF masing-masing 
adalah 1.237, 1.380, dan 1.435 (lebih kecil dari 10). Hal ini menunjukkan bahwa tidak terjadi multikolonieritas.

3. Uji Heteroskedastisitas

Dengan uji Glejser ditemukan bahwa nilai signifikansi uji t adalah lebih besar dari alpha $5 \%$ yang menunjukkan bahwa data terbebas dari masalah heteroskedastisitas.

4. Uji Autokorelasi

Nilai Durbin-Watson adalah 2.004. Tabel Durbin-Watson untuk $\mathrm{k}=3$ dan $\mathrm{n}=42$ ditemukan $\mathrm{d}_{\mathrm{u}}=1.383$. Karena $1.383<2.004<$ $4-1.383$ atau $1.338<2.004<2.662$ maka hipotesis null yang menyatakan bahwa tidak terdapat autokorelasi positif maupun negatif tidak dapat ditolak.

\section{Penilaian Goodness of Fit Model}

1. Koefisien determinasi bernilai 0.246 yang berarti bahwa kemampuan model dalam menerangkan variasi variabel agency cost adalah sebesar $24.6 \%$, sedangkan sisanya sebesar $75.4 \%$ diterangkan oleh variabel lain yang tidak dimasukkan ke dalam model.

2. Uji F

Signifikansi uji F bernilai 0.012 (lebih besar daripada 5\%) menunjukkan bahwa model yang digunakan adalah layak dan dapat digunakan untuk analisis selanjutnya.

3. Ujit

Struktur modal berpengaruh positif dan hampir signifikan (p-value bernilai 0.05) terhadap kinerja perusahaan. Sedangkan ukuran perusahaan dan agency cost tidak berpengaruh signifikan pada alpha $5 \%$.

Tabel 2. Hasil Analisis Regresi Pengaruh $\mathrm{X}_{1}, \mathrm{X}_{2}$, dan $\mathrm{Y}_{1}$ terhadap $\mathrm{Y}_{2}$

Coefficients $^{3}$

\begin{tabular}{|c|c|c|c|c|c|c|c|c|}
\hline \multirow[b]{2}{*}{ Model } & & \multicolumn{2}{|c|}{ Unstandardized Coefficients } & \multirow{2}{*}{$\begin{array}{c}\text { Standardized } \\
\text { Coefficients }\end{array}$} & \multirow[b]{2}{*}{$t$} & \multirow[b]{2}{*}{ Sig. } & \multicolumn{2}{|c|}{ Collinearity Statistics } \\
\hline & & $B$ & Std. Error & & & & Tolerance & MF \\
\hline 1 & (Constant) & .095 & 3.087 & & .031 & .976 & & \\
\hline & In debt to equity & .280 & .138 & .317 & 2.025 & .050 & .808 & 1.237 \\
\hline & Inta & -.064 & 154 & -069 & -414 & .681 & .724 & 1.380 \\
\hline & Inagencycostinterest & .282 & .165 & .288 & 1.708 & .096 & .697 & 1.435 \\
\hline
\end{tabular}

Persamaan matematika model jalur 2:

$$
\mathrm{Y}_{2}=0,317 \mathrm{X}_{1}-0.069 \mathrm{X}_{2}+0.288 \mathrm{Y}_{1}+0.868 \mathrm{C}_{2}
$$

Penelitian ini menemukan nilai signifikansi $\mathrm{F}$ sebesar 0.012 yang menunjukkan bahwa model layak dan dapat dipakai untuk uji selanjutnya. Uji t menunjukkan tidak ada satu pun variabel yang signifikan pada alpha $5 \%$ padahal data sudah memenuhi asumsi multikolinieritas. Namun nilai p-value struktur modal menunjukkan 0.05. Berarti struktur modal sangat hampir berpengaruh terhadap kinierja perusahaan.

\section{Pengujian Hipotesis Ketiga}

Pengaruh tidak langsung struktur modal dan ukuran perusahaan terhadap kinerja perusahaan melalui agency cost sebagai intervening variable dapat dilihat di bawah ini:

- Pengaruh tidak langsung (indirect effect) $\mathrm{X}_{1} \mathrm{ke}$ $\mathrm{Y}_{2}$ melalui $\mathrm{Y}_{1}=0,370 \times 0.288=0.107$

- Pengaruh tidak langsung (indirect effect) $\mathrm{X}_{2} \mathrm{ke}$ $\mathrm{Y}_{2}$ melalui $\mathrm{Y}_{1}=-0.487 \times 0.288=-0.140$

Hasil uji statistik pada tabel 2 di atas menunjukkan bahwa agency cost tidak berpengaruh signifikan pada alpha $5 \%$ terhadap kinerja perusahaan (p-value 0.095). Oleh karena itu pengaruh tidak langsung struktur modal dan ukuran perusahaan terhadap kinerja perusahaan sebagaimana yang dihitung di atas juga tidak signifikan.

\section{Pengaruh Struktur Modal dan Ukuran Perusahaan terhadap Agency Cost}

Pada pengujian hipotesis pertama ditemukan bahwa struktur modal berpengaruh positif dan signifikan terhadap agency cost. Ukuran perusahaan berpengaruh negatif dan signifikan. Temuan ini sesuai dengan Lin (2006). Kebijakan hutang meningkatkan agency cost. Perusahaan besar mempunyai lebih sedikit discretionary expense. Perusahaan besar lebih efisien.

Temuan menunjukkan bahwa jika hal-hal lain dianggap tetap, peningkatan hutang sebesar $1 \%$ persen akan meningkatkan proksi agency cost, dalam hal ini adalah perbandingan discretionary expense dengan penjualan bersih, sebesar $0.333 \%$. Kemungkinan hal tersebut disebabkan oleh beban bunga hutang yang meningkat seiring dengan meningkatnya jumlah hutang.

Hal ini tidak sesuai dengan Jensen dan Meckling (1976) dalam Cao (2006) yang menyatakan bahwa penggunaan hutang dalam struktur modal dapat mencegah pengeluaran yang tidak penting dan memberi dorongan pada manajer untuk mengoperasikan perusahaannya dengan lebih efisien. Temuan ini juga tidak sejalan dengan Brigham dan Daves (2004) yang menyatakan bahwa penggunaan hutang yang tinggi dalam struktur modal dapat menimbulkan ancaman kebangkrutan sehingga mengurangi agency cost. Hal tersebut terjadi karena manajer akan mengurangi pengeluaran yang tidak penting agar dapat membayar hutang. Selain itu dalam masa kesulitan keuangan pihak kreditur juga akan 
mengawasi sehubungan konteks governance insolvency (Fachrudin, 2008).

Temuan ini menemukan bahwa rata-rata rasio hutang terhadap ekuitas adalah 0.59 dengan standar deviasi 0.88. Jumlah yang tidak tinggi ini mengindikasikan bahwa perusahaan tidak sedang dalam kesulitan keuangan sehingga terdapat kemungkinan bahwa manajer tidak berhati-hati dalam pengeluaran discreationary expense, karena itu pengaruh struktur modal terhadap agency cost tidak negatif, melainkan positif.

Kehatian-hatian manajer dalam pengeluaran kas terjadi pada saat perusahaan yang memiliki banyak hutang sedang berada dalam financial distress, contohnya adalah pengurangan jumlah karyawan. Demikian juga saat krisis ekonomi 1997-2000, perusahaan tidak kesulitan keuangan pun melakukan penghematan biaya (Fachrudin, 2007). Penelitian lanjutan dapat meneliti pengaruh struktur modal terhadap agency cost pada perusahaan yang mengalami financial distress.

Ukuran perusahaan berpengaruh negatif terhadap agency cost. Koefisien unstandardized beta -0.463 menunjukkan bahwa jika hal-hal lain dianggap tetap, peningkatan ukuran perusahaan sebesar 1\% akan menurunkan agency cost sebesar $0.463 \%$. Indikasinya adalah bahwa 1 ) perusahaan besar dapat mengurus discretionary expense dengan bijak sehingga efisien, 2) adanya skala ekonomis, serta 3) perusahaan besar mempunyai penjualan bersih yang lebih besar dari pada perusahaan kecil. Hasil uji ini sesuai dengan temuan Lin (2006).

Agency cost dipengaruhi oleh struktur modal dan ukuran perusahaan. Semakin tinggi penggunaan hutang dalam struktur modal meningkatkan proksi agency cost. Semakin besar ukuran perusahaan menyebabkan discretionary expense semakin berkurang. Kemungkinan bahwa 1) tidak terdapat konflik agency antara manajer dan pemegang saham mayoritas dalam perusahaan di industri dasar dan kimia yang terdaftar di Bursa Efek Indonesia. Hal ini terlihat dari fakta bahwa beberapa perusahaan memiliki direksi yang juga pemegang saham atau keluarga pemegang saham tersebut. Masalah agency terjadi karena ketidaksejajaran kepentingan direksi dan pemegang saham. Jika direksi juga pemegang saham maka kesejajajaran kepentingan mungkin terwujud sehingga tidak ada masalah agency. Penelitian lanjutan dapat menguji masalah ini. 2) Masalah agency cost tidak dapat dikurangi dengan penggunaan hutang. Dengan demikian diperlukan cara lain untuk mengatasinya seperti keberadaan komisaris yang benar-benar independen serta komite audit dalam rangka menegakkkan good corporate governance.
Pengaruh Struktur Modal, Ukuran Perusahaan, dan Agency Cost terhadap Kinerja Perusahaan

Pengujian hipotesis kedua menunjukkan bahwa struktur modal hampir berpengaruh signifikan terhadap kinerja (p-value 0.05). Beta yang positif menunjukkan bahwa penggunaan hutang dapat meningkatkan imbal hasil bagi pemilik perusahaan. Teori mengatakan bahwa ROE adalah return on assets (ROA) dikali dengan leverage (Jones et al. 2009). Jadi leverage dapat mempengaruhi ROE. Hal ini terjadi karena pembiayaan dengan hutang menimbulkan beban bunga yang tetap harus dibayar. Jones et al. (2009) menyatakan bahwa leverage dapat meningkatkan imbal hasil bagi pemegang saham (favorable leverage), tapi dapat juga merugikan pemegang saham (unfavorable leverage). Level ROA tertentu dapat meningkatkan kinerja menuju ROE yang lebih tinggi melalui penggunaan pendanaan hutang yang bijaksana. Sebaliknya penggunaan pendanaan hutang yang tidak bijaksana dapat menyebabkan ROE lebih rendah daripada ROA (Jones et al. 2009). Penelitian ini hampir menunjukkan bahwa leverage meningkatkan imbal hasil kepada pemegang saham. Berarti dana dari hutang digunakan dengan cara yang baik sehingga meningkatkan laba. Perusahaan juga masih mempunyai laba sebelum bunga dan pajak yang cukup baik.

Moeljadi (2006) mengatakan bahwa apabila Return on Assets (ROA) lebih besar dari tingkat bunga, maka sebaiknya pemenuhan kebutuhan dana diambil dari modal pinjaman, sebab penambahan leverage akan menaikkan ROE. Jika perusahaan memaksakan diri untuk menggunakan modal sendiri, baik emisi saham baru maupun laba ditahan, maka secara teoritis akan menurunkan ROE. Jika ROA lebih kecil dari tingkat bunga, maka keperluan dana sebaiknya diambil dari penambahan modal sendiri, baik melalui emisi saham maupun laba ditahan, sebab akan meningkatkan ROE. Jika perusahaan memaksakan menambah leverage maka ROE akan menurun. Jika ROA sama persis besarnya dengan tingkat bunga pinjaman, maka penambahan atau pengurangan hutang tidak akan mempengaruhi ROE. Penelitian ini menunjukkan bahwa penggunaan hutang hamper meningkatkan ROE. Hal ini mengindikasikan bahwa ROA yang diperoleh hampir lebih besar dari tingkat bunga pinjaman. Penelitian selanjutnya dapat meneliti pengaruh perbandingan ROA terhadap tingkat bunga terhadap ROE. 
Ukuran perusahaan tidak berpengaruh terhadap kinerja perusahaan. Hal ini menunjukkan bahwa ukuran perusahaan bukan jaminan bahwa perusahaan akan memiliki kinerja yang baik. Huang (2002) serta Talebria et al. (2010) juga menemukan bahwa tidak terdapat pengaruh ukuran perusahaan terhadap kinerja perusahaan. Tetapi Lin (2006) serta Wright et al. (2009) menemukan bahwa ukuran perusahaan berpengaruh positif terhadap kinerja.

Agency cost tidak berpengaruh signifikan pada alpha $5 \%$ terhadap kinerja perusahaan. Artinya beban perusahaan tidak mempengaruhi ROE. Hanya, karena struktur modal hampir berpengaruh terhadap kinerja perusahaan, terdapat kemungkinan bahwa beban bunga akan berpengaruh terhadap kinerja perusahaan. Penelitian lebih lanjut diperlukan untuk melihat kemungkinan ini.

Koefisien agency cost yang positif dan p-value yang bernilai 0.095 mengindikasikan bahwa jika alpha diperluas menjadi $10 \%$ maka semakin banyak discreationary expense maka semakin tinggi ROE. Kemungkinan memang beban bunga yang mempengaruhi ROE tersebut dan memang beban-beban tersebut sudah wajar karena meningkatkan ROE.

Temuan mengenai pengaruh agency cost ini tidak sejalan dengan Lin (2006) dan Wright et al. (2009) yang menemukan bahwa agency cost berpengaruh negatif dan signifikan terhadap ROE, artinya bila agency cost dibiarkan membengkak, maka hal tersebut dapat mengurangi pencapaian keuntungan kompetitif yang berdampak negatif terhadap kinerja.

\section{Pengaruh tidak Langsung Struktur Modal dan Ukuran Perusahaan terhadap Kinerja Perusahaan Melalui Agency Cost sebagai Intervening Variable}

Agency cost tidak berpengaruh signifikan terhadap kinerja pada alpha 5\%. Walaupun struktur modal berpengaruh terhadap agency cost namun agency cost tidak berpengaruh terhadap kinerja. Hal ini menunjukkan bahwa tidak terdapat pengaruh struktur modal terhadap kinerja melalui agency cost. Dengan kata lain pengaruh tidak langsung struktur modal terhadap kinerja tidak signifikan. Ukuran perusahaan secara langsung tidak memiliki pengaruh terhadap kinerja perusahaan. Demikian juga secara tidak langsung, tidak berpengaruh signifikan terhadap kinerja perusahaan melalui agency cost.

Dapat dikatakan bahwa semakin tinggi hutang, beban bunga meningkat sehingga discreationary expense meningkat, tetapi peningkatan discreationary expense tidak meningkatkan kinerja. Kinerja yang digunakan adalah ROE, yaitu rasio laba bersih dibandingkan dengan ekuitas pemegang saham. Discreationary expense adalah beban yang dikeluarkan berdasarkan kebijaksanaan seorang manajer, meliputi beban operasi, beban non operasi, beban bunga, serta gaji dan upah (Lin 2006). Dalam hal ini discreationary expense adalah jumlah beban usaha ditambah beban bunga. Pada saat penggunaan hutang meningkatkan beban bunga maka discreationary expense meningkat. Dalam format laporan laba rugi, penjualan dikurang beban pokok penjualan dikurang discreationary expense menghasilkan laba usaha. Laba usaha ditambah pendapatan (beban) lain-lain dan ditambah manfaat (beban) pajak menghasilkan laba bersih. Jika rasio discreationary expense terhadap penjualan signifikan mempengaruhi struktur modal dan agency cost tidak signifikan mempengaruhi ROE, berarti hal tersebut kemungkinan dikarenakan manfaat (beban) lain-lain dan beban pajak tidak signifikan mempengaruhi ROE.

Format Laporan Laba Rugi disajikan dalam gambar 2 bawah ini untuk memperjelas pengaruh dan keterkaitan antara struktur modal, ukuran perusahaan, agency cost, dan kinerja perusahaan:

\begin{tabular}{|c|c|}
\hline & 2011 \\
\hline Penjualan Bersih & $\mathrm{XX}$ \\
\hline Beban Pokok Penjualan & $\mathrm{XX}-1$ \\
\hline Laba Kotor & $\mathrm{XX}$ \\
\hline \multicolumn{2}{|l|}{ Beban Usaha } \\
\hline Penjualan & $\mathrm{XX}$ \\
\hline Umum dan Administrasi & $\mathrm{XX}$ \\
\hline Jumlah Beban Usaha & $\mathrm{XX}-1$ \\
\hline Laba Usaha & $\mathrm{XX}$ \\
\hline Pendapatan (Beban) Lain-Lain & $\mathrm{XX}$ \\
\hline Laba (Rugi) sebelum Manfaat (Beban) Pajak & $\mathrm{XX}$ \\
\hline Manfaat (Beban) Pajak & $\mathrm{XX}$ \\
\hline Laba (Rugi) Bersih & $\mathrm{XX}$ \\
\hline
\end{tabular}

Gambar 2. Format Laporan Laba Rugi

Dari format Laporan Laba Rugi di atas terlihat jelas bahwa jika peningkatan hutang meningkatkan discreationary expense maka beban usaha bertambah besar. Beban bunga atau beban keuangan yang merupakan bahagian dari pendapatan (beban) lain-lain juga meningkat. Namun jika discreationary expense berpengaruh positif terhadap kinerja, maka berarti terdapat pendapatan (beban) lain-lain atau manfaat (beban) 
pajak yang semakin besar. Hal tersebut dapat disebabkan oleh meningkatnya penghasilan bunga, keuntungan penjualan aset tetap, koreksi pajak, keuntungan dalam mata uang asing, manfaat pajak, serta beban pajak yang berkurang karena pendanaan dengan hutang. Kenyataannya discreationary expense tidak berpengaruh signifykan pada alpha 5\% terhadap kinerja yang artinya pendapatan (beban) lain-lain atau manfaat (beban) pajak tidak mempengaruhi kinerja.

\section{KESIMPULAN}

Struktur modal berpengaruh positif dan signifikan terhadap agency cost. Hal ini sejalan dengan Lin (2006) bahwa kebijakan hutang meningkatkan agency cost. Namun tidak sejalan dengan pandangan yang mengatakan bahwa peningkatan hutang dalam struktur modal dapat mengurangi masalah agency. Ukuran perusahaan berpengaruh negatif dan signifikan terhadap agency cost. Hal ini mengindikasikan bahwa perusahaan besar lebih efisien.

Struktur modal, ukuran perusahaan, dan agency cost tidak berpengaruh signifikan terhadap kinerja perusahaan. Hanya struktur modal yang hampir signifikan (p-value 0.05). Koefisien positif menunjukkan penggunaan hutang dalam struktur modal membawa dampak yang baik terhadap kinerja perusahaan. Ukuran perusahaan memang meningkatkan efisiensi discreationary expense namun tidak meningkatkan ROE.

Tidak terdapat pengaruh tidak langsung struktur modal dan ukuran perusahaan terhadap kinerja perusahaan melalui agency cost. Secara langsung struktur modal hampir berpengaruh terhadap kinerja perusahaan. Namun secara tidak langsung tidak berpengaruh. Ukuran perusahaan tidak berpengaruh terhadap kinerja perusahaan baik secara langsung maupun tidak langsung.

Penelitian selanjutnya dapat mengembangkan penelitian ini dengan meningkatkan jumlah pengamatan, misalnya dengan mejadikan seluruh perusahaan manufaktur yang terdaftar di BEI menjadi populasi sasaran. Dengan demikian hasil penelitian ini menjadi lebih robust. Peneliti selanjutnya juga dapat meneliti pengaruh struktur modal terhadap agency cost pada perusahaan yang mengalami financial distress agar pembuktian empiris mengenai pandangan bahwa peningkatan hutang dapat mengurangi agency cost semakin jelas. Penelitian mengenai persentase pemegang saham yang merangkap direksi terhadap jumlah pemegang saham juga dapat dilakukan dalam kaitannya dengan agency cost. Hal ini untuk melihat apakah jika terdapat peningkatan kesejajajaran kepentingan direksi dan pemegang saham maka masalah agency dapat dikurangi.
Selanjutnya untuk lebih mendalami masalah kaitan struktur modal terhadap kinerja, peneliti selanjutnya dapat menambahkan variabel beban bunga dan beban pajak sehingga akan terlihat jelas apakah beban bunga hutang atau penghematan pajak dari hutang yang lebih dominan mempengaruhi kinerja.

Implikasi manajerial yang diberikan adalah bahwa investor dan calon investor sebaiknya tidak terlalu terfokus pada ukuran perusahaan dalam berinvestasi karena belum tentu perusahaan besar menghasilkan kinerja yang lebih baik walaupun perusahaan besar dapat menghemat discreationary expense-nya.

Kemungkinan tidak terdapat indikasi masalah agency di dalam perusahaan-perusahaan dalam industri dasar dan kimia yang terdaftar di Bursa Efek Indonesia berdasarkan sampel yang diteliti karena peningkatan hutang tidak menurunkan agency cost dan bahkan semakin besar ukuran perusahaan agency cost semakin berkurang. Berarti terdapat efisiensi dalam perusahaan. Selain itu, jika alpha dinaikkan menjadi $10 \%$, terdapat pengaruh positif struktur modal dan agency cost terhadap kinerja-artinya upaya-upaya yang dilakukan manajer menghasilkan return bagi pemegang saham.

Penelitian ini menunjukkan bahwa penggunaan hutang meningkatkan beban namun tidak signifikan meningkatkan kinerja. Manajer perlu mempertimbangkan trade off antara beban bunga dan penghematan pajak ini.

\section{DAFTAR PUSTAKA}

Atkinson, Anthony A, Rajiv D. Banker, Robert S. Kaplan, and S. Mark Young. 1997, Manangement Accounting, Second Edition, Prentice Hall International Edition.

Bouresli, Amani Khaled. 2001. Managerial Incentives and Firm Performance: Evidence from Initial Public Offering, Dissertation, The Graduate School Southern Illinois University.

Brigham, Eugene, F. and Phillip R. Daves. 2004. Intermediate Financial Management, Eight Edition. Thomson.

Calisir, Fethi, Cigdem Altin Gumussoy, A. Elvan Bayraktaroglu, and Ece Deniz. 2010. "Intellectual Capital in the Quoted Turkish ITC Sector", Journal of Intellectual Capital, Vol. II(4), page 537-553.

Cao, Bolong. 2006. "Debt Financing and the Dynamic of Agency Cost", Dissertation, University of California, San Diego. 
Fachrudin, Khaira Amalia. 2007. Analisis Kesulitan Keuangan Perusahaan-Studi pada Perusahaan Manufaktur yang Terdaftar di Bursa Efek Jakarta Tahun 1995-2005, Disertasi, Program Pascasarjana, Fakultas Ekonomi. Universitas Brawijaya. Malang.

Fachrudin, Khaira Amalia. 2008. Kesulitan Keuangan dan Personal, USU Press, Medan.

Ferdinand, Augusty. 2006. Metode Penelitian Manajemen. Edisi Kedua. Badan Penerbit Universitas Diponegoro. Semarang.

Huang, Lan-Ying. 2002. FDI Scale and Firm Performance of Taiwanese Firms in China. Dissertation. H. Wayne Huizenga School of Business and Enterpreneurship. Nova Southeastern University.

Husnan, Suad. 2001. "Corporate Governance dan Keputusan Pendanaan: Perbandingan Kinerja Pemegang Saham Pengendali Perusahaan Multinasional dan Bukan Multinasional." Jurnal Riset-Akuntansi, Manajemen, Ekonomi, PPAM STIE Yo, 1(1), hal. 112 .

Jones, Charles P., Siddharta Utama, Budi Frensidy, Irwan Adi Ekaputra, dan Rachman Untung Budiman. 2009. Investment-Analysis and Management (An Indonesian Adaptation), Wiley, Penerbit Salemba Empat.

Keng, I, Wen-Yi Lin, and Y. Angela Liu. 2008. "Loan Guarantees for Related Parties and Control Mechanisms". Working Paper. National Chung Cheng University, Taiwan, Academic-papers.org/ocs2/session/Papers / Poster/508.doc.
Lin, Kun Lin. 2006. Study on Related Party Transaction with Mainland China in Taiwan Enterprises, Dissertation, Departemen Manajemen, Universitas Guo Li Cheng Gong, China.

Moeljadi. 2006. Manajemen Keuangan-Pendekatan Kuantitatif dan Kualitatif, Jilid 1, Edisi Pertama, Bayumedia Publishing.

Naiker, Vic, Farshid Navissi, VG Sridharan. 2008. "The Agency Cost Effects of Unionization on Firm Value", Journal of Management Accounting Research, Vol. 20, pp. 133-152.

Talebria, Ghodratallah, Mahdi Salehi, Hashem Valipour, and Shahram Shafee. 2010. "Empirical Study of the Relationship between Ownership Structure and Firm Performance: Some Evidence of Listed Companies in Tehran Stock Exchange", Journal of Sustainable Development. Vol 3 (2), pp. 264-270.

Wang, Shiing -Wu. 1991. "The Relation between Firm Size and Effective Tax Rates: A Test of Firms' Political Success". The Accounting Review. January, Vol. 66 (1), pp. 158-169.

Wright, Peter, Mark Kroll, Ananda Mukhreji, Michael L. Pettus. 2009. "Do the Contingencies of External Monitoring, Ownership Incentives, or Free Cash Flow Explain Opposing Firm Performance Expectations?", Journal Management Governance, 13, pp. 215-243.

Yamin, Sofyan dan Heri Kurniawan. 2009. SPSS Complete-Teknik Analisis Statistik Terlengkap dengan Software SPSS, Penerbit Salemba Infotek. 